\title{
TCC's
}

\section{ESTUDO DE VIABILIDADE DE USINA SOLAR FOTOVOLTAICA EM POSTO DE COMBUSTÍVEL}

\author{
EDUARDA BIFFI|UnC \\ MARI AURORA FAVERO REIS | UnC
}

\section{INTRODUÇÃO}

Aumento na demanda de energia elétrica e necessidade de redução de energia por origem fóssil têm levado à busca de novas fontes na geração da eletricidade limpa e sustentável. Entre as possibilidades, a energia fotovoltaica tem conquistado espaço na matriz energética por ser considerada limpa, autônoma e gerar redução de custos nas faturas de eletricidade, principalmente em demandas elevadas.

Neste intuito, foi realizado um estudo com objetivo de analisar a viabilidade técnica e econômica para instalação de uma usina na geração de energia solar fotovoltaica em um posto de combustível na cidade de Ipumirim (SC). A escolha desse ambiente, como objeto de estudo, foi devido a três fatores: (a) elevado consumo de energia, tornando o consumidor investidor potencial para a implantação do sistema; (b) ampla cobertura plana, que possibilita a disposição das placas de modo a obter maior incidência solar; (c) incentivos futuros à abastecimento de carros movidos por energia elétrica.

\section{O PROJETO}

O projeto para a implantação do sistema foi desenvolvido em três etapas: (i) coleta de dados junto ao cliente, como demanda de consumo, características da cobertura (área, sombreamento e posicionamento); (ii) levantamento de dados junto a fornecedores da tecnologia e dimensionamento do sistema a ser instalado a fim de atender a demanda; (iii) estudo de viabilidade econômica utilizando planilha eletrônica.

O projeto demonstrou viabilidade técnica favorável devido a localização e ausência de obstáculos que possam gerar sombreamento nas placas (Figura 1), possui uma área ampla de cobertura $\left(736 \mathrm{~m}^{2}\right)$, em estrutura plana, possibilidade de instalação dos módulos conforme o ângulo desejado para melhor incidência solar.

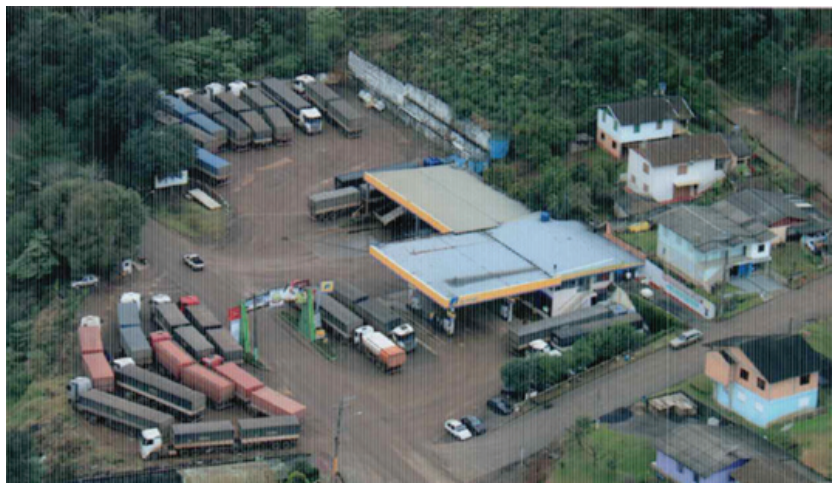

Figura 1 - Imagem aérea da cobertura do posto de combustível. Fonte: Dados da pesquisa (2018).

A análise das faturas de julho de 2017 a junho de 2018 demonstra que o posto de combustível teve um consumo total de $10.843 \mathrm{kWh}$ para o período analisado, gerando

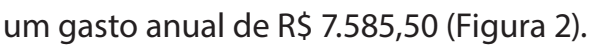

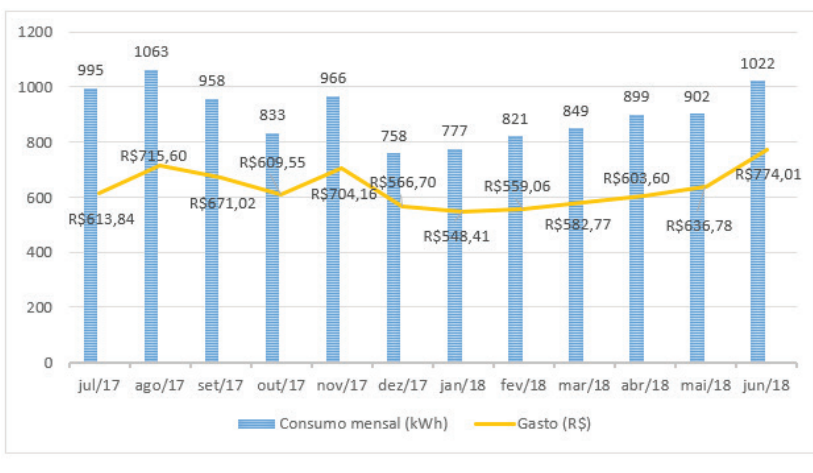

Figura 2 - Dados do consumo e custo com energia elétrica Fonte: Dados da pesquisa (2018).

Na viabilidade econômica todos os valores de investimentos iniciais foram coletados em 2018 (BIFFI; REIS, 2019) e equacionaram resultados equivalentes a tempos semelhantes para retorno do investimento, sendo possível verificar que a adoção de um sistema solar fotovoltaico é um investimento que irá gerar retorno após seis anos de instalação. 
Com base em aplicações financeiras, aumentos tarifários e vida útil dos equipamentos foram realizados os estudos de viabilidade econômica, com cálculo de payback (Figura 3), como em estudo anterior (REIS; REIS JÚNIOR; PERIN, 2020), considerando a taxa mínima de atratividade (TMA).

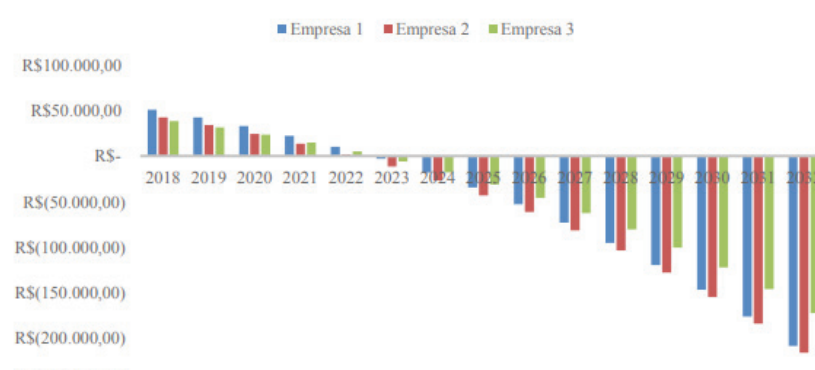

$\operatorname{RS}(250,000,00)$

Figura 3 - Fluxo de caixa

Fonte: Autores (2018)

Considerando que os inversores possuem vida útil de 10 a 15 anos e os painéis superior a 20 anos, os resultados do estudo demonstram viabilidade técnica e econômica para implantação do sistema na edificação, contribuindo para a redução dos custos com energia elétrica e sustentabilidade.

\section{REFERÊNCIAS}

BIFFI, E.; REIS, M. A. F. Estudo de viabilidade de usina solar fotovoltaica em posto de combustível na cidade de Ipumirim. VII ENSUS - Encontro de Sustentabilidade em Projeto. Anais...Florianópolis:UFSC, 2019Disponível em: <http://ensus2019.paginas.ufsc.br/files/2019/05/ VOLUME-3.pdf >. Acesso em: 21 out. 2019

REIS, M. A. F.; REIS JÚNIOR, P.; PERIN, D. L. Sustentabilidade energética em escola pública. MIX Sustentável, v. 6, n. 3, p. 37-44, 18 jun. 2020 